Popular Music and Society

\title{
Queerly Turkish: Queer Masculinity and National Belonging in the Image of Zeki Müren
}

\section{Spencer Hawkins}

To cite this article: Spencer Hawkins (2018) Queerly Turkish: Queer Masculinity and National Belonging in the Image of Zeki Müren, Popular Music and Society, 41:2, 99-118, DOI: 10.1080/03007766.2016.1212625

To link to this article: https://doi.org/10.1080/03007766.2016.1212625

曲 Published online: 22 Aug 2016.

Submit your article to this journal $\pi$

Џlll Article views: 296

View Crossmark data ־

Citing articles: 1 View citing articles 


\title{
Queerly Turkish: Queer Masculinity and National Belonging in the Image of Zeki Müren
}

\author{
Spencer Hawkins iD
}

\begin{abstract}
This article offers an explanation for the lasting appeal of Turkish cross-dressing singer Zeki Müren (1931-96). His performances on stage, film, and television interweave avant-garde, modern, and oldfashioned elements. The success of these performances registers Turkish society's ambivalence about modernity, masculinity, and sexuality. Müren's queer performances conjure an imaginary public that spans the divisions within Turkish culture, such as that between nostalgia for the Ottoman past and aspirations for national belonging based on European models. The article concludes by examining some recent appropriations of Müren's image, to show that Müren continues to represent an imaginary, unified Turkish society.
\end{abstract}

Star performer Zeki Müren (1931-96) is perhaps the most revered singer of Turkish classical music in Turkey, despite the uncomfortable facts that he cross-dressed during most of his musical performances and his homosexuality was an all but open secret. A star on the radio, screen, and television and at nightclubs, Müren queered Turkish masculinity-that is, he performed it convincingly, while also exposing its contradictions. His performances reproduce gender norms in such an ambiguous yet widely celebrated way that the very notion of masculinity comes to seem less oppressive in its demand for conformity. Over his career, he expanded his audience from the urban bourgeoisie who frequented upscale nightclubs, to the rural peasantry who increasingly attended his movies, and finally to include whole families, including children, in his audience through colorful televised music videos. By the time of his death in 1996, he had won the heart of the whole republic, and his image remains politically efficacious today for its service as a common ground for Turks with opposed political views. In the twenty-first century, Turkey has seen an unprecedented anti-secular turn. Turkey is as politically divided as ever, and Müren's virtuosity and patriotism along with his gender transgressions make him a contested figure who represents an imaginary, unified Turkish society.

This article explains Müren's place in Turkish culture primarily through a semiotic reading of Müren's performances across different media and venues, but this reading is supported by an historical and theoretical discussion of Müren's gender performance. I argue that Müren bought his iconic status by presenting himself as an exception in every regard. He was exceptional enough as a patriot and musician to become an exception to normal gender expectations - but being a Turkish patriot required evidence of masculinity, and 
thus required that every queer performance interwove familiar, normal gender performance elements. The concluding section will explore the latest triumph of Müren's culturally unifying legacy: his carefully wrought public image has posthumously taken on political significance for minority rights issues in Turkey. Shortly before the June 2015 general elections in Turkey, the smiling face of Zeki Müren could be seen in campaign ads on Twitter and in graffiti around Istanbul in support of Turkey's newest political party, the Public Democratic Party (HDP). The choice of Müren's face is bold and telling: as a new political party focused on ensuring rights and protections for Kurds, other minorities, and women, the HDP appropriated the image of the beloved figure. Voting for a new party was risky for disgruntled voters. If the HDP failed to achieve $10 \%$ of the general election vote, then the votes for HDP would translate into additional seats for the ruling party. In a socially conservative political climate like Turkey's, why would a party represent itself with a queer figure when they appeared on the ballot for the first time and their first task was to appear viable enough for their supporters to vote for them?

Müren's afterlife as a political icon suggests that the promise of a politically unified Turkey that he embodied during his lifetime still operates in Turkish culture. His offstage patriotism (leaving his estate to the Turkish foundations for veterans and education) and onstage queer self-presentation (feminine movements, flamboyant make-up and outfits) allowed compromises between cultural forces, such as between modern Turkish gender categories and the fluid Ottoman sexuality that these categories repressed. This is the question under investigation in this article: How does a figure who deviates so obviously from normal self-presentation appeal to audiences across the deep divisions in Turkish society? The answer will require us to consider the range of media strategies that Müren mastered as well as his subtle, skillful expression of unspoken fears, wishes, and fantasies of a society undergoing major cultural and political transitions.

\section{Personal Note: American Admirer}

This article applies semiotic and cultural critical tools to an area in which I am not an expert. I am writing neither as a Turk nor as a Turcologist, but as a comparatist, whose research has thus far focused on Western European letters. It was only after I accepted an academic job in Turkey that I sought to understand Turkish culture through the music. Around the world, people express identity through musical taste. Ethnomusicologist Josh Kun claims that music has a special power to produce an imagined community in the form of an "audiotopia," a space of belonging afforded by music consumption, which may be experienced privately or communally, but which nonetheless feels universal in scope (Kun). My experience corroborates Kun's thinking insofar as my experience of appreciating non-English language music lends me a feeling of experiencing the affective dimensions of a foreign language and its associated cultures.

My appreciation for Zeki Müren began with YouTube listening, where I encountered Müren's earnestness, conveyed in his virtuosic voice and in his intense, melancholy gaze. His uncanny resemblance to a style-conscious, middle-aged woman inspired my admiration for his courage. The melodies did not appeal to me at first, but eventually they did as I began learning to sing the songs, one after another. I first admired the resonant clarity of his vocal timbre, which never wavered when he modulated his pitch or even when he sang with vibrato. To my ear, this suggested a singer who loved beautiful melodies, and did not belabor the pathos of the melodies (although Müren does occasionally do just that, when 
he begins to weep or to shout lyrics such as, "Gitme sana muhtacim!" ("Don't go! I need you!") at the end of some songs, as if he were a soap opera star pursuing a lover who is abandoning him (1982)). As a trained singer, I admire clear, unembellished vocal styles that show humility before the music itself. After first becoming a fan of Müren's music, I learned what a complex role Müren plays in mediating fierce contradictions in Turkish society.

\section{Historical Note: Reform and Repression of Ottoman Gender in the Turkish Republic}

In order to understand why masculinity is such a contested ground in Turkish culture and to appreciate Müren's deftness in navigating it, we have to describe some effects of the so-called "Atatürk reforms" on gender expression in Turkey. The behaviors and signs that constituted masculinity changed visibly in the political transition from the Ottoman Empire to the Turkish Republic. Western societies became exemplary for the new Turkey, and while the state promoted democracy, women's rights, and secularism, it demanded that its citizens adopt a more Western-looking personal style. According to Turkish cultural critic Orhan Koçak, the republican state produced a double-bind wherein Turks could be rebuked either for ignoring or for completely following Western norms of dress and behavior (see Gurbilek 602). In 1934, the founding government of Turkey abolished the wearing of traditional religious garments outside a worship context. Like the 1925 law which demanded that all male civil servants wear Western-style hats (fedora, top hat, etc.) and which banned any traditionally Muslim type of hat (fez, turban, etc.), the dress laws outlawed male Ottoman clothes since they were intended to restructure existing social hierarchies, which had hitherto been based in large part on claims to spiritual status among clerically affiliated men (imams, ulemas, etc.), a status marked by hats and other clothing. Women could still legally appear in public with headscarves or even face veils, but they were forbidden at workplaces and schools. The reformers interpreted women's traditional headwear as expressing submission to religious authority, just as traditional male headwear claimed that authority for the wearer.

Hyper-masculine (stoic, paternalistic, aggressive) behaviors and attitudes became a last recourse when Turks felt that the clothing reforms marked Turkish identity as inferior to Western identity. The severity of the hat law sometimes challenged Turks' masculinity directly by leading to cross-dressing, when men would don women's hats if they could not find a man's "Western" hat in order to avoid imprisonment or corporal punishment (Genç). Cultural critic Nürdan Gürbilek claims that Turkish men also felt a special anxiety about Turkish society's belatedness in joining "modernity." She cites a fear of living in perpetual childhood among the fears that accompanied the "modernization" of gender in Turkey. It is easy to see how Müren's feminine appearance, musical virtuosity, melancholy songs, and often childlike, happy demeanor could have made him a timely figure of triumph over these fears (Arslan 187).

Turkey's nationalist cultural reform movement advocated uniform gender expressions beyond clothing. Poet, sociologist, and politician Ziya Gökalp, a key spokesperson for Turkey's cultural reforms, argued that Turkey could become modern without losing its culture if it "returned to" ancient Turkic customs (Gökalp 115). Even he argued a place for the cross-dressing exception, by remarking on the gender deviance of Turkish male shamans as exemplary of enlightened ancient Turkish customs; the shamans demonstrated a "feminist" 
respect for female occult power by dressing and behaving like women and by managing "even [to] get pregnant and bear children" (Gökalp 112). For non-shamans, however, everyday manners defined gender, and Gökalp affirms the "chivalry" of the ancient Turks: "A man always respected his wife and would have her ride in the cart while he walked behind" (Gökalp 113). For Gökalp, rigid conformity to gender roles would be among the determinants of Turkishness. The Turkish nationalist movement that Gökalp helped to form would meanwhile reject gender-fluid habits of Ottoman society such as homoerotic court poetry, cross-dressing zenne dancers, and homosocial communalism. Gökalp informed President Mustafa Kemal Atatürk's reform policy, which heavily policed "modern" Westernized gender expression as it all but abolished Ottoman clothing style. Between these policies and the gradual expulsion of nearly all Christians and Jews through population exchanges, dress and appearance began to look increasingly homogeneous in early twentieth-century Turkey.

This programmatic promotion of masculinity reduced previous outlets for nonheterosexual practices that had existed within the former Ottoman Empire. While still moralistic and restrictive towards women, Ottoman sexual mores did not necessarily condemn what contemporary Western discourse would call male bisexuality (Traub 24). Ottoman court performances included zenne dancers, cross-dressing male belly-dancers, who received sexual attention from their male audiences (Pullen 262). While the Turkish nationalist movement began in the early nineteenth century, its cultural agenda emerged after the Republic of Turkey was founded in 1923-and only after a revolutionary army overthrew the French, British, Greek, and Armenian occupiers, who had seized and divvied up the former Ottoman Empire's land after World War I. Since Turkey's victory, the most visible face of Turkishness has been Atatürk, the commanding general in the War of Independence and the Republic's first president. The semi-autocratic statesman is as visible as ever today in the photographs displayed prominently in shops, restaurants, bars, airports, ferries, and public buildings throughout Turkey. His attention to detail in his fine European-style garments displayed sartorial refinement as a mark of the status that Turkey's liberating war hero deserved. The fame of Atatürk's self-designed outfits reduced the fear that a carefully dressed man might be stigmatized as a dandy ( $z \ddot{u} p p e$ ), and perhaps Atatürk's outfits even granted acceptability to Müren's attention to detail in designing his own outfits. While their gender expressions differ greatly, both men are clean-shaven-part of the softer, European male look promoted by Atatürk.

The cultural reform laws had further significance for musicians since they also proscribed "Ottoman" musical genres and endorsed "Turkish" or "modern” ones (see Tekelioğlu). Ottoman traditions were thus stigmatized in musical style, religious expression, and gender expression. Müren won the public heart by straddling normalcy and stigma in all three areas, and by thus embodying past and future orientations. When Müren died in 1996, celebrities, statesmen, biographers, and journalists expressed their mourning for him among other ways by calling him a "model citizen" (Stokes 35). In a Turkish music television clip of "Tesellim olsun" (1985), Atatürk's face, with its fearless, paternal gaze, appears as a small insignia in the upper right corner, while Müren's face, with heavy eye shadow, downcast gaze, and resolute but heartbroken pout, occupies the camera frame.

As a foreign observer, living in suburban Turkey, I have the impression that clothing and grooming (make-up vs. thick facial hair) express gender here, but that other gender markers matter less. Public consumption of ice cream and cigarettes, for instance, may not be gendered. Normative heterosexuality does not impede what I might perceive as public displays of affection between men. One anthropologist points out the striking similarity 
between Western gay public affection and straight Turkish homosocial behavior: affectionate stroking ("massaging"), handholding, and close physical contact are normal between men. (The anthropologist speculates that these gestures result because of the sparse opportunity for sexual contact with Turkish women [Cardoso 574-75].) One Turkish author found in "conversations with Turkish men" that "sexual play with other men plays a rather important role in young men's sex life, especially in rural areas. While still young, playing the 'passive' role apparently does not disturb them unduly" (Necef 74). Turkish women face stigma for having sex with a man out of wedlock (even when they are raped), and a similar stigma transfers to adult men who allow themselves to be anally penetrated by another man. ${ }^{1}$

Although effeminacy is stigmatized, the Turkish public makes an exception for celebrities. Sociologist Mehmet Ümit Necef reports a popular explanation for the acceptance of gender deviance among artists such as Müren: “Turks explain their admiration for these [gender deviant] artists by pointing to their artistic talent and to the fact that nearly all artists are crazy and strange" (Necef 73). Necef articulates the most socially acceptable contemporary form of male bisexuality in Turkey: effeminate men are referred to as ibne in Turkish and seen as appropriate sexual objects for dominant, bisexual men, or kulampra. While the kulampra is an accepted part of society, the effeminate ibne is stigmatized. The public culture allows Müren to avoid the stigma, but further explanation is needed to understand Turks' reverence for Müren. While we could imagine that the reverence for Müren's work registers admiration for his merit and success in spite of the stigma against his feminine gender expression, I argue instead that Müren's queerness adds to his appeal by creating a fantasy space that unites tradition and modernity and bridges irreconcilable differences and divisions in Turkish society.

\section{Zeki Müren: Repressed Queerness Returns}

Müren modeled an alternative form of Turkish masculinity by navigating Turkish cultural semiotics. The upcoming sections explore why Turkish society has received Müren's self-presentation so well, and, in order to understand what is at stake in Müren's transgressions, I import the contemporary concept “queer." His queer performance disrupts ordinary gender expectations whether or not it suggests the performer's queer sexuality. In the context of this article, the word "queer" refers to a gender-non-conforming style of self-presentation that subverts through the suggestion of possible deviant sexual identification. When applying normative Western concepts like "queerness" to Turkey, I run the risk of misreading what is occurring there and creating problems that exist only from a foreign perspective. Political theorist Dipesh Chakrabarty writes that historicism, as a European concept, "is both indispensable and inadequate in helping us to think through the various life practices that constitute the political and the historical in India" (6). Valerie Traub expands on this principle of tentative borrowing in the introduction to Islamicate Sexualities: "To adopt Chakrabarty's terms, it may not be possible to create Islamicate sexuality studies without recourse to the analytical categories of European and Anglo-American gay/lesbian/queer historicism" (28-29). Such are the cultural translation problems that accompany this work.

In the most extensive academic study on Müren's position as a cultural icon, ethnomusicologist Martin Stokes tentatively uses the word "queer" to describe Müren's transgressiveness. ${ }^{2}$ Stokes discusses Müren's rise to fame, the media frenzy around him, the popular response, and the nostalgia that his death left behind, nostalgia for the fantasy of 
Turkey unified by love for him. Müren finds in music a vehicle to resist the burden of the post-Reform-era gender norms. Popular music was the perfect anti-repressive form for several historical reasons: the influence of Egyptian music endured-in bootleg recordings-in spite of state censorship; song lyrics had ambiguously gendered language ever since erotically framed communication between courtiers and the royal family during the so-called Ottoman "Age of Beloveds," and the Islamic mystical tradition had introduced erotic language into Islamic high culture ever since the efflorescence of medieval Persian erotically coded religious poetry. ${ }^{3}$ Thus, Müren's queerness subtly imported the most subversive aspects of traditional Middle Eastern culture.

Yet in his offstage rhetoric, Müren claimed traditional masculinity. In 1970, he listed Eastern and Western, secular and religious examples of men who have not incurred stigma for wearing feminine outfits: boxers, Judo artists, "our" [Ottoman or Turkic] ancestors, sultans, and Caucasian tribesmen. "Are monks women?" he taunts (qtd in Bengi 104). He then writes that he would not cross-dress if it did not please his audiences-a confession that he dresses to look exceptional, like an exotic warrior from the past, rather than like a normal, modern, Turkish man. An apocryphal anecdote exemplifies Müren's masochistic relationship to masculinity. When Kenan Evren, a leader of the 1980 military coup in Turkey, asks Müren why people call him "pasha” (a title given to Turkish army generals), Müren retorts with a homophobic insult: "This nation was so angry about what you did during the military coup, but they couldn't be very open with their anger. Rather than calling you and your colleagues faggots (ibne), they called me pasha" (Cakirlar 38). Müren is imagined here utilizing homophobic tropes to put down an unpopular military leader, but elsewhere he spoke admiringly of the Turkish military and donated much of his estate to Mehmetçik Vakfi, a foundation that supports Turkish soldiers and veterans.

Müren made an effort to pass as not only masculine, but also as heterosexual. Magazine articles supported Müren's image as a philanderer by reporting that he had many affairs with women. According to an anecdote told by a friend of Müren's, Müren lost his temper when a teenage boy shouted, "Hey sister Zeki!" Müren responded, "I fuck your mother! Now who are you calling sister?" after which he smacked the teenager in the face (qtd in Çınar). LGBT activists today still reject Müren for his refusal to identify as gay. Although he was a known patron and financial supporter of gay clubs in Bodrum, a journalist for the LGBT magazine Kaos GL declared in 2007 that cis-gendered, heterosexual celebrity singer Hande Yener was a better LGBT “icon” than Zeki Müren or Bülent Ersoy because Yener, at least, claims to "like" gay people — thus affirming gay identity—a risk that Müren understandably avoided (Görkemli 51).

An exemplary straight patriot offstage, Müren does not abandon masculinity onstage, but in combining feminine elements in his acts, he defamiliarizes and thus queers Turkish masculinity. Müren established his reputation as a virtuoso before becoming famous as a campy entertainer. The gender-deviant extravagance of his style was just one among his many innovations. Also innovative for the genre, he created dynamic effects by varying his position relative to the microphone. Unusually for a Turkish art-music singer, he ended songs with a qaflah, a flourishing cadenza familiar from Arab art music, which was considered an improvisation in response to a particular audience. By his own account, he taught himself to enunciate carefully while singing in order to differentiate himself from art singers he heard on the radio during his childhood (Stokes 57-61). His vocal style sounds queer to an American listener. As musicologist Simon Frith points out regarding American 
pop music, the vocal styles that listeners find sexy often leave the singer's gender barely recognizable, such as males singing in head voice, pure timbre, and high pitch-like Müren (Frith 195). Adding to this appeal, the T-shaped stage that he designed let him move closer to audience members while performing and thus giving the listener a fantasy of intimacy with his stage persona. He captured the Turkish imagination with a unique persona that augmented the effect of his virtuosity. (He claimed not to have trained under a master, as had been traditional in Turkish art music.) Imagination captured, the Turkish public was ready for his queer outfits, postures, and movements so crucial to his music videos. $\mathrm{He}$ would eventually be called the "Sun of Art" (Sanat Güneşi).

Song lyrics were an important part of Müren's subversion. His lyrics almost uniformly express the same abject lover's position, and, as scholars have observed, abjection lets Müren register Turkish fears of inadequacy (Arslan) and exhibit his punishment for his gender deviance (Cakirlar). Müren sings as a lover deprived of his object (which Turkish grammar leaves gender neutral): in the song, "Bir Gülü Sevdim” (1984), "I loved a rose....For one season./Ah! S/he up and left" ("Bir gülü sevdim.... Tek mevsimlikmiş. Ah! Kaçiverdi”). Then in "Tesellim olsun" (1985), "Considering that you won't wipe my tears,/smile one last time as a comfort for me" ("Madem ki gözyaşımı dindirmiyorsun,/son bir defa gülümse, tesellim olsun."), and in "Seni Sordum Yildızlara" (1989), "You said you mourned my absence./Why did you get sick of me so quickly?" ("Yokluğumda özlüyurdun./Neden benden bıkıverdin?").

Müren's stylistic transformation and media forays exhibit strategies that work towards the same goal: synthesis of Turkish cultural divisions (Kemalist and Islamist, migrant and elite, queer and straight) by performing and queering the codes of Turkish Republican masculinity. By analyzing three of Müren's types of performance, I hope to show how Müren oscillates between queer performance and traditional performance and the gestures within Müren's queer performance that code his queer presentation as familiar and normal. Public meaning and personal meaning coincide in the analysis of a public figure, who connects us with intense immediacy to others within the same "audiotopia," the imaginary collective of appreciative music listeners. ${ }^{4}$ Müren enables an imagined public, one that remains in the realm of fantasy.

Every scholarly discussion of Müren remarks on the apparent contradiction: he presents as queer or feminine in a culture with rigid norms of masculine dress-even for performers-yet is revered as a national treasure. Film historian Umut Tümsay Arslan draws on Nurdan Gürbilek's analysis of Turkey's “masculinizing struggle” to find in Müren's cinema appearances a figure who survived the abjectness of Turkish masculinity. Zeki Müren's homosexuality was an open secret that produced what he had to offer the imagination:

he was never openly referred to as "gay." This censored text is constantly at work in Zeki Müren's image. While on the one hand enabling fears of effeminacy, loss of masculinity, or fixation in childhood to be played out in relation to domineering characters, this secrecy on the other hand, turns homosexuality into a libidinous investment that is not publically acceptable. (Arslan 194).

Müren exhibited queer tendencies onstage but his closeted sexuality is part of the text and amounts to what Eser Selen called "work of sacrifice” where Müren's "gender ambivalence remained existential to his stage performance and his work, for which he sacrificed his queer subjectivity offstage. Between the 'manly' and the 'unmanly', the ways by which he managed his queer subjectivity are emblematic, exemplary and perhaps indicative of an economy where his work of sacrifice was rendered valuable" (738). Stokes also describes Müren's 
ambiguous gender performance as efficacious for his fame, "Müren allowed the question of identity to be publicly construed in a responsible and citizenly way" (70). To achieve this public acceptance, Müren transforms queerness into something socially acceptable.

Art critic Cuneyt Cakirlar understands Müren's “work of sacrifice” as a masochism in which Müren invites the Turkish public to take sadistic pleasure. In 2009, artist Erinç Seyman commissioned a marksman to fire at targets in the shape of Müren's face on a giant canvas. This work attracted the attention of Cakirlar, who claims that the penetration of the piece by bullets signifies how the pleasure of sodomy and the pain of Müren's wounds around closeted sexuality together amount to the masochistic relationship he had to aggressive masculinity (42). Cakirlar's study shows that something subtle is at work in Müren's queerness: it sabotages Turkish masculinity by being its target, while also reveling in the freedom gained within his abject, closeted position. The image formed from bullet holes reflects the way that, precisely by staying in the closet, Müren was performing the kind of masochism that, in the end, only added to his queer image.

In a variant on the claims of Stokes, Selen, Cakirlar, and Arslan, who indicate a loss of self as the price of Müren's success, I argue that Müren performs Turkish masculinity while rendering it queer, unfamiliar, and therefore less oppressive in its demand for conformity. I will discuss three areas where Müren queers Turkish masculinity: live performances in nightclubs, film roles, and music videos for television. These deserve special attention because every public registers gender expression differently. What counts as a transgression depends on the conventions for the performance type, and the course of the performance itself establishes contexts that can neutralize transgressions as well as rendering them more visible. Thus the next three sections examine the range of Müren's performance types, as well as the range of expressive styles within discrete performances on stage, screen, and television. He would change his outfit from formal to campy from one act to the next within one nightclub performance. Similarly, he acted in varying film roles, and within each role, he played sentimental, highly excitable figures who changed facial expressions, moods, and actions from one scene to the next. And his music videos exhibit a range in costumes worn and settings occupied, affects projected and songs selected, but more importantly within each video, forceful and delicate gestures, bravura and coyness combine to make Müren so ambiguous a figure of queer masculinity. The ambiguity could be couched as reactionary progressivism, such as Gökalp promoted: in this case, finding one's liberation in the reclaiming of Ottoman topoi.

\section{On the Nightclub Stage}

Zeki Müren's live performances were particularly popular among women. The overhauling of women's role in Turkish society at the founding of the Republic (1923) is well known. The leadership took measures to include women in higher education and in the workforce alongside men. For most of the span of the Ottoman Empire, women were not often seen unaccompanied in public. But the republican policies were meant to include women in public life. Thus, when Zeki Müren donned modern women's clothes on stage, it signified the arrival of femininity as a position so worthy of public presentation that a male performer would sacrifice his more securely established privilege to partake in it. Even if cross-dressing was not socially acceptable, its implicit affirmation of womanhood was so necessary a gesture that its significance compensated for the disturbance of normal gender 
performance. Perhaps this cross-dressing, along with his self-presentation as sensitive and religious, contributed to Müren's being the first nightclub performer to perform for mostly female audiences in his matinee shows (Stokes 46).

Ever since ancient tragedy, stage performance has accommodated deviant and unusual behavior that would be stigmatized elsewhere, which means that Müren's queerness could pass more easily onstage, especially considering that he proved himself a master of an elite musical genre (Selen 730). After a well-received radio debut on 1 January 1951, Müren saw his career as a nightclub performer take off. His audience was the urban elite who enjoyed the rarely performed Ottoman court style classical Turkish music. This musical style was less widely popular than arabesk, a musical style derived from Egyptian film music, and banned on the radio by the Westernizing government, but widely consumed by Istanbul's growing population of rural economic migrants, who came to work in Istanbul when manufacturing expanded under the newly elected Democratic Party's liberalization policies (Özgür 178). Zeki Müren, like Bülent Ersoy after him, distinguished himself from other singers by proving himself capable of singing in especially demanding musical modes (makam) and in a more "authentic" or "elite" musical genre (Altinay 212). Despite the conservative genre choice, by the 1960s, Müren had not only begun singing in the popular arabesk style but also fully embraced a subversive onstage personal style: often appearing with effeminately coiffed hair, women's evening maquillage, and colorful garments that deviate wildly from the international dress code of men's formalwear. His suits were often pink or sequined. He designed sequined dresses, boas, miniskirts, and brightly colored blazers, and he gave his outfits names such as “The Prince from Outer Space," "Dr. Zhivago's Lover," and "Purple Nights."

As a stage performer, Müren appealed to Turkishness in its Westernized republican and its traditional Middle Eastern strands. He performed regularly in upscale Turkish nightclubs (gazinos) such as Maksim, a club that established the careers of many popular Turkish musicians. There is little published information about Müren's gazino performances, and thus I will draw on a recent interview that Dilara Elbir conducted with her grandmother Nurten Turan, who attended Müren's early performances in Istanbul and his later ones in Bodrum, as she followed his musical career with admiration. In Müren's first performances, he demonstrated his character as a "patriot" and "a great gentleman," traits that have belonged together since Atatürk. While on stage, he spoke to the audience in "Istanbul Turkish," which at that time meant "proper," distinguished speech, free of rural regional accents. But unlike Atatürk, whose patriotism did not imply religious piety, Müren appeared "religious" to his audience, and did not eat or drink onstage (unlike Müzeyyan Senar, a singer of similar fame, who did rakı shots onstage). In this way, his stage persona combined secular class distinction with religious sensibility, bridging a sore division within Turkish culture.

After he had established his reputation, he began changing his outfits up to four times during a show. A typical stage performance could consist of three parts:

accompanied by three different costume changes. He designed his own costumes as well as those of his musicians and backing vocalists, and also the décor for his performances and the choreography of the dancers. He would start his performance dressed in a tuxedo and sing major works from Ottoman court/Turkish classical music. While performing these songs, Müren would adopt a fixed posture and gaze to signal his respect for this genre, as if there was nothing between him and the music. Following these heavy and slow-paced pieces, he would move on to lighter songs from Turkish art music, wearing more colorful suits. Finally, Müren would appear in suits with sparkling accessories or even mini-skirts with platform shoes and sing popular, dynamic, fast-paced tunes without regard to genre. (Selen 737) 
This phase of his career established his reputation as a star and as a gender queer male (to continue using the North American term), but his cross-dressing on stage could have been chalked up to a showman's glitz (many compare his style and career to Liberace's or David Bowie's), acceptable through the Kemalist welcome of cultural novelty as long as it had a Western precedent (or unconsciously registered nostalgia for Ottoman gender expression without the negative consequences of doing so explicitly). In the 20th century, a combination of factors, including music broadcasting censorship, Western influence, Egyptian influence, and the melancholy associated with urban migration resulted in what one musicologist calls the "spontaneous synthesis" of Turkish popular music-a new genre that incorporated regional and global traditions (Tekelioğlu 196). The stage of live performance has generally been theorized as a place that contains horrors and perversions that people would prefer not to admit into their ordinary lives. When we consider that gazino performances entertained migrants coming from rural Anatolia to work in cities-before they became expensive bourgeois events - we see why Müren needed to appeal across the rural/urban divide, which likely meant that he had to appeal across Turkey's deep Islamist/ secularist divide as well.

\section{Film Roles: Masculinity Torn Between Women}

Perhaps because of the wider exposure that film afforded, Müren's starring roles in several films did not reach the queer excesses of his stage performances. Yet the open secret of his homosexuality adds to the pathos that the viewer feels when watching the tribulations of Müren's characters; he always plays a boyishly innocent heterosexual man, who gets sabotaged by manipulative women and other cunning villains. Müren became a film star during the explosion of Turkish cinema. In the 1950s through 1980s, Turkey boasted one of the most prolific cinema in the world. At some point, television soap operas overtook the function of the melodramatic films of Yeşilçam Studios (Turkey's mid-century version of Hollywood or Bollywood). But, as several of the era's prominent directors aver in interviews for the recent documentary Remake, Remix, Rip-Off, there are only about 31 stories in the world-and therefore there is no legitimate basis for enforcing copyright laws for plots borrowed from American movies (Kaya). This rationale sounds like a reference to Russian structuralist Vladimir Propp's theory of the 31 narratemes (e.g., the hero searches for advice, the villain deceives the hero), but the borrowed elements tend to be soundtracks (from movies such as The Godfather and Raiders of the Lost Ark) and highly specific characters or settings (from movies in popular genres ranging from Star Wars to The Exorcist). Closer in scale if not in type to Propp's narratemes, however, Yeşilçam also had its own implicit encyclopedia of tropes that it recycled in its films: the rejected romantic hero turns to excessive drinking (either rakı or Johnny Walker Black Label) right before a plot reversal, lovers discuss their unstable prospects near the Bosphorus, and one of any two romantic rivals wields greater economic power than the other.

Yeşilçam melodramas had tightly formulaic plots. Because of the extreme volume of movies being made and watched at movie theaters, Yeşilçam film producers had few qualms about repeating extremely similar movie plots that would appeal to the main base of the Turkish viewing public: poor rural Turks, or poor Turks who had migrated from rural areas to cities, primarily Istanbul or Ankara, for work. The plot presumed to resonate with this public was the melodrama where a poor man and a rich woman fall in love, but their love 
proves impossible through the emergence of a rich male rival, whom the woman's father would rather see her marry. ${ }^{5}$ The point where the rich male rival would emerge is where Zeki Müren film plots run queer. In The Awaited Song (Beklenen Şarkı, 1953), Müren plays a poor young music teacher, who falls in love with his student, a rich young woman. When the father objects, however, Müren moves on and tries to marry a different woman. While his characters always seem like boyish victims of circumstance and never devious womanizers, he almost always becomes involved with more than one woman over the course of a film plot.

When we read male rivalry for women as if it were natural, it marks the rivals' particular identities as insignificant and thus also naturalizes the patriarchal "traffic in women," the reduction of women to exchangeable goods (Rubin). Eve Sedgwick has produced an influential analysis of romantic love triangles in her work on the British novel. Oedipal models of male rivalry (such as René Girard's) inherit from Freud the notion that rivalry determines one's object of desire, and therefore the experience of rivalry produces normal or pathological identity. Such models eclipse the significance of the rivals' prior identity traits, which often decide the outcome of the rivalry: age, race, and sex may matter, but Sedgwick lists gender, language, class, and power (Kosofsky Sedgwick 27). Power never operates invisibly in the world of Müren's melodramas. Rivals often harm one another or avenge themselves on an uncooperative object by exercise of power such as rejection, accusation, blackmail, and deception. It is particularly common in Yeşilçam films for a rich male suitor and a poor male suitor to compete for the affection of the same woman, but in Müren's films a different pattern prevails: two women fight over the male lead, whose name is "Zeki."

The class-conflict love triangle plot had a mass appeal and reflected the fantasies and experiences of poor rural migrants. This is the same demographic that responded to arabesk music, whose lyrics also took up the theme of homesickness and aspiring to class mobility through unlikely romantic connections with wealthier partners until the 1990s when that wave of migrants and their children had assimilated into the urban working class and no longer felt alienated due to their rural roots. As one scholar writing on arabesk describes it: "In the 1950s, 1960s, and 1970s, arabesk singers sang about their unreciprocated love for the girls of the modern world-i.e. the fast girls of the modern world-who rejected them because of their traditionalism" (Özgür 183). The impossibility of competing against wealthy, sophisticated men for the love of urban women was a common theme during the boom years of Turkish film melodrama.

Many of Zeki Müren's films play out a slightly different fantasy. Müren plays a character named "Zeki Müren" who is involved in heterosexual romantic relationships but who comes under the control of a powerful woman. (In this section, "Zeki” refers to the eponymous characters in the films - and "Müren" refers to the actor.) In various films, these women take pleasure in his beautiful voice. Arslan has written persuasively about the symbolic function of these women, focusing particularly on the woman who controls Zeki's movements in Broken Record (Kırık Plak, 1959):

She orders, controls, and procures sex on command; this position of domination that blurs the boundaries of the sense of self invites subjugation and is represented in a close-up of her long fingers stretching out towards the bedside lamp after she has persuaded Zeki to acquiesce. This besieging, encircling force which subordinates and drags into darkness is like the embodiment of the fear of the unconscious, the fear of losing the boundaries of one's identity, the fear of sexuality, and the fear of the masses with her inability to know what she wants....In Zeki's words, the masses and Nermin imply one another: "I hit it off with the public even on our first encounter. I became the fan, the captive of the masses before me. But this has been 
crushing for me. In return for all that I have gained, I have lost my sense of self; I have become Nermin's slave." (209)

Arslan mounts strong evidence that Zeki is figuratively "married" to the public in the film. One could go further: these female characters who stand in for Müren's public remind us that Müren, the queer performer, appears to be not the marrying type-perhaps, the films imply against the background of Müren's queer stage persona, because he is only attracted to men.

Some of Müren's films contain love triangles of the traditional type: rivalry among men for a women. These exceptions include Life is Sweet Sometimes (Hayat Bazen Tatlidır, 1962) and Vagrant (Berduş, 1958), where Müren plays a poor shoe-shine, whose name means "Vagrant" (Berduş). As if to distance this character, who competes for female attention, from Müren's stage persona, this is one of the few films in which the protagonist's name is not Zeki. In this movie, Berdus falls in love with a rich woman, who is fond of him and has him employed as the gardner at her house, but does not entertain the thought of a relationship. He discovers that she is engaged to another man from her economic class. Berduş's former employer at a tavern coerces him into robbing the house of his beloved. The climax occurs when Berduş tries to expose him and save the woman and her property, but dies in a shootout with his accomplice. As if to suggest to audiences that the actual Müren has good reasons (such as concern for personal safety) for not engaging in rivalry over women, this is the only one of his films where his character dies at the end.

In Life is Sweet Sometimes, the Zeki character is straight as always, but his affect shows someone who already knows "how to be gay," as David Halperin puts it. His signs of initiation into gay subculture thus do not exclude plausible deniability, but his coy, exaggerated head movements and sarcastic smiles express what cruising gay subculture does best: the suggestion that one could be performing gay belonging. But, even when the Zeki character onscreen acts queer, the gayness of the actor is expressly denied in the same film through the other character Müren plays: a doppelganger character whose dopey facial expressions and antics show a complete lack of the refinement that characterized Müren's stage persona. This double act warns the viewer that Müren can play any role on camera. He will not let us believe that we are watching a gay actor just because he might act gay on camera.

In Broken Record, Zeki gives a live performance, which is broadcast to a radio public, whose diverse inclusiveness is emphasized through a montage sequence. It includes families, homosocial male groups some in bars and others in prison, and homosocial female groups some in evening gowns and others in headscarves. In short, the whole of Turkish society loves Zeki, but the focal listener in the live performance is the woman who exploits his success, forces him to be romantically involved with her, and keeps him away from his ideal listener, the woman who accompanies him on the piano during rehearsals, but hears his performances only over the radio. Through the symbol of Müren's gay body, her distance during performances is part of her appeal, not for the typical heterosexual reason-that it makes her a challenge to acquire-but for a gay one-because she stays away, potentially freeing him to meet men. The triangulation in Zeki's movies keeps him away, for a time, from committing willingly to either woman, which could express the subtext that both women, in fact, function as a convenient cover up, or "beard," for the closeted homosexuality of the Zeki character in the film.

His film career also greets Turkish publics across the Islamist/secularist divide. Müren performed in Ottoman nostalgia period films as well as in contemporary set melodramas. But the plots of these two film types did not differ in structure. Both Scribe (Kâtip, 1968) 
and Wedding Night (Düğün Gecesi, 1966) follow a structure where Müren plays a singer who is romantically involved with one woman, and then experiences success as a singer around the time that he meets a second woman. The resolution of the movie turns primarily around his choice between the women. As usual for Turkish melodramas, one of the two romantic rivals uses her superior economic power to help advance Zeki's musical career while monopolizing his attention, and thus at least temporarily marginalizing her rival. In Scribe, Zeki plays an Ottoman court scribe in love with a childhood girlfriend. But, while he is singing on a gondola one day, his beautiful voice attracts the attention of the sultan's mother (a very powerful position in Ottoman courts), who gives Zeki the opportunity to sing the religious chants in a mosque. ${ }^{6}$ After his success there, his powerful patroness invites him to train the sultan's wives in music. The sultan-mother's delight in watching him-enjoying her power over the abjectly controllable Zeki-is visible. When he sees his beloved again as a harem girl, their impossible love becomes a familiar Ottoman topos, one all too suited to expression in a plaintive duet. ${ }^{7}$

As mentioned above, this movie plot structure queers the traditional Turkish movie plot: the rivalry is usually between two men over a woman. When a rich and a poor man vie for a woman's attention, we are reminded more readily of the patriarchal condition where men more often control wealth and use it to "traffic in women." In the new Turkish Republic, some of Atatürk's most important reforms were meant to promote women's access to education, the workforce, and the public sphere in general. This queerness thus could thus appeal to secularists and to Islamists: for the secularist, the forthright woman "patron" in Wedding Night shows that artists had made imaginative space for the entry of women into the once patriarchal realm of the entertainment industry. In Scribe, the aristocratic woman who has Zeki sing the call to prayer recalls the strange reversals of gender and sexual power associated with the Ottoman empire-from the wiles of harem women to the homoeroticism of the male courtiers (see Andrews and Kalpakli). Seeing Müren's characters involved with multiple women at once (though with a large measure of shame) may have appealed to fantasies of Ottoman masculine power. From the early years of Islam until the fall of the Ottoman Empire, polygyny was pervasive, not only for the sultan, but also for any men who could afford a large family. Polygyny was justified on religious grounds as a way of protecting women from poverty, one of the basic concerns of early Islam, since in the pre-Islamic Middle East the economy provided few niches for unattached women other than slavery or prostitution (Andrews and Kalpakli 16). The Ottoman nostalgic fantasy is one of universal welfare and cosmopolitan inclusiveness, but Müren also plays on Kemalism's Westward orientation to allow a space for his flamboyant showmanship. As in his gazino performances, Müren's film persona straddled the wishes and fantasies of the two rival strands of modern Turkish culture-all the while queering both models of masculinity.

\section{Television: The Language of Color and Gesture}

Nothing demonstrates Müren's unifying power better than the fact that he was a television star at a time when Turkish television had only one channel (TRT-1), which was quickly replacing the domain of the Turkish film industry. From the mid-1970s to today, Turkish television soap operas have been Turkey's leading cultural export, mostly consumed in other Muslim countries. The wide viewership of Turkish national television means that many Turks and foreigners saw Müren's television appearances, which were at least as 
daring in terms of queer self-presentation as his nightclub appearances. Protected by the distance afforded by tele-mediation, but also more exposed than ever, Müren relied on his stardom to connect with audiences in shiny, colorful clothes, heavy make-up, coquettish smiles, and campy gestures.

His television appearances connected him with a new audience: children. One Turkish acquaintance of mine, who is currently in her 30s, told me that she used to love watching Müren perform on television, and that she called him "Teyze Zeki” (“Aunty Zeki”) to the amusement of her family. The Zeki Müren telephone line project, initiated by Beyza Boyacıoğlu, includes a call from someone else who saw Müren on television as a child, thought that he was a woman, and used to cry because she wanted so badly for Müren to be her mother (Giaimo). Through the medium of television, Müren entered the domestic space, where his queerness was visible to children, the members of society most protected from sexuality. While his television performances exhibited an extremely gaudy yet convincingly feminine style, he compensated for this queer effect in so far as his outfits were never particularly tight or revealing. He dressed like a middle-aged woman, thus a woman not conventionally regarded as a sexual object, and thus gender queer, without being sexually deviant. Nevertheless, Müren's shiny, colorful clothes, dramatic performance, and swooning lyrics presented a middle-aged woman who still wanted to be seen and who had not forgotten the promises of romantic love.

The fact that his hands did the dancing while his body was mostly stationary is an interesting metaphor for the divide that Müren always preserved in his performances: his essence, his personal identity as a patriotic, "normal" Turk remained unquestionable-and his confidently unmoving torso recalls this certainty of his position. Meanwhile, his appearance, the show he gives, queers traditional gender norms for the sake of art. The liberation that this implies could impugn his straight maleness, but looking female, being unmarried, and passing as a straight male is Müren's coup. Like Liberace, to whom he is often compared, he remained in the closet while developing a television persona with an ever more daring cross-dressing camp act.

In this third phase of his career, the cross-dressing that was already familiar from photographs and publicity posters for his gazino performances was presented with new technology. According to a recent retrospective exhibition about Zeki Müren, new consumers of radio and television technologies relished their new access to Müren; jokes emerged: "Does this radio play Zeki Müren?” And “Can Zeki Müren see me too?” The music videos, mostly produced later in his career, show Zeki looking alternately bold and coy. When he points to his chest defiantly in the video for "Bulamazsin" (1995), his expression is powerful but slightly besumed. His vocal range is typically grand in this song: again showcasing his virtuosity and almost hermaphroditic gender. His voice goes high and heady in the refrain; when it goes low, it growls with vibrato, as if in parody of masculine bravura. He makes wild hand gestures, and then holds his hands in fixed positions, gently shaking them as if constrained but not panicked, having all the while a smugly triumphant facial expression that signals, "You know you want me." Meanwhile, his lips glisten with lip gloss, adding an even clearer irreverence for gender conventions. All of this is especially striking when seen with the large orchestra of moustachioed men wearing sport coats in royal blue (a popular color for Turkish business suits) and black pants. They are playing the instruments that traditionally go with Turkish art music, including Western instruments like the violin and Middle Eastern ones with the kanun (a small harp-like instrument played with finger picks). 
In 1987, the Turkish Radio and Television Administration produced research on the demographics of viewer preferences, and found that Turkish art music and Turkish popular music were the two most popular genres, and that music programming was the second most popular after locally produced series (Televizyon 2: Program Yayınları Kamuoyu Araştırması [Ocak-Şubat 1987] 29, 130). With viewers under 24 years old and with male viewers generally, the music programming was the most popular program of all. Although Müren was famously popular with both sexes, I imagine that young men questioning their hypermasculine culture especially were extremely intrigued by the space of possibility allowed in the alternative masculinity implied by Müren's ways of moving and gesturing on television.

\section{Zeki's Afterlife: The Unifying Exception}

The figure of the unifying exception takes on great significance in a country so deeply divided along social and political lines of identification. ${ }^{8}$ While many Turks mourned the death of the polite, civilized public figure in 1996, progressives saw the acceptance of a queer figure as cause for hope that Turkish public discourse would one day begin to acknowledge gender, linguistic, and ethnic differences within Turkish society (Stokes 69). When Müren's name and face appeared on promotional material for the Public Democratic Party (HDP) campaign for the general election on 7 June 2015, it showed that Müren's appeal remains broad and politically mobilizing. It is worth briefly narrating Turkish current political events in order to show why the HDP found potential in Müren's privileged outsider status as a socially acceptable queer man.

Müren's ability to belong, and even to form a public, from the position of a non-normative identity made him an icon for the newly formed HDP, a political party formed to appeal to ethnic Kurds. The HDP movement gained urgency when many Kurds felt outrage at Turkey's lack of support for military intervention on behalf of their relatives suffering and dying under ISIS in Northern Syria and Iraq. Before the problems across the borders, Kurds living in southeastern Turkey had suffered police brutality and interference with public life for decades, including school and hospital shutdowns-part of the government's aggressive efforts to disarm Kurdish separatist groups. Differing public opinion over this off-and-on civil war has made Kurdish issues some of the most divisive in Turkey. The words of Atatürk, "Happy is the one who says 'I am a Turk,"' was formerly a required daily pledge in public schools. Kurds rejected the pledge because the identity "Turk" had been used to ignore their particularity: in the war against Kurdish separatists, the Turkish government used to refer to Kurds as "mountain Turks" as a way of undermining Kurdish identity difference.

While outrage at the Turkish government is nothing new for the Kurdish movement, working within the system is a new strategy. The strategy, known as Türkiyelileşmek, literally "becoming part of Turkey," was encouraged after 2013 when President Recep Tayyip Erdoğan encouraged greater autonomy for Kurdish politicians in the southeast and even allowed Kurdish politicians to talk with imprisoned PKK leader Abdullah Öcalan. The electoral successes of the HDP represent a new achievement for Kurdish Turks in attaining representation through the democratic process, and it seemed that the Kurdish movement as a whole had given up separatist goals of forming a Kurdistan nation independent of Turkey (Yildirim 11). Turkish government officials once welcomed the change as the end of the war between Kurdish militants and the Turkish army, but ever since Kurdish militants 


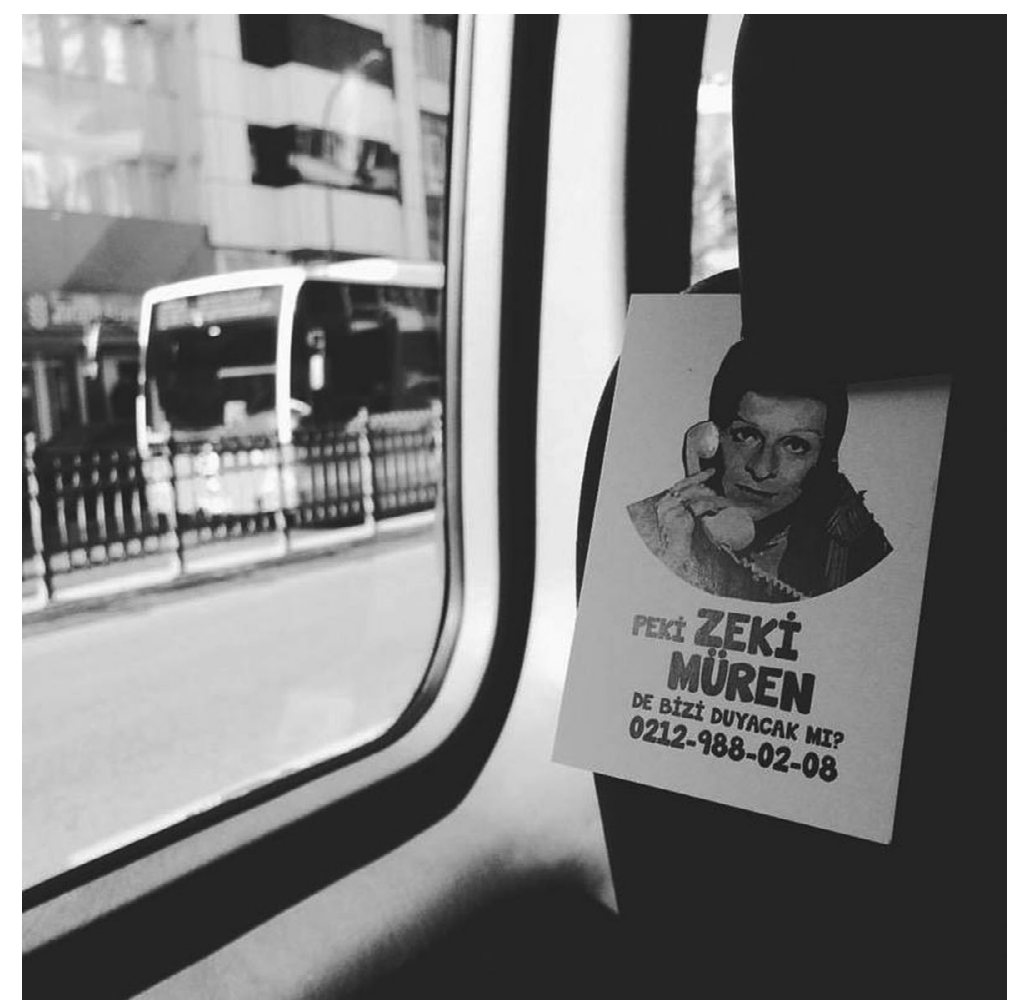

Figure 1. Poster for Zeki Müren hotline on a public bus in Istanbul, Turkey, 2016. (Text:"So, can Zeki Müren hear us, too?"). Photograph: Beyza Boyacıoğlu.

have received international support for intervening in Syria in 2014, Erdoğan has ceased supporting Türkiyelileşmek and waged an intense crusade to delegitimize the HDP (Worth).

Since the ruling party is the religiously conservative AKP, and the old secularist and nationalist parties (CHP and MHP) did not support the Kurdish cause either, the HDP appealed to those groups most disaffected by the recent government's nationalist, religious conservative laws, domestic aggressions, and inaction in Syria. To brand themselves as a progressive, "young" party they hired a social media volunteer team to create memes for the campaign (Altuntaş). Several memes refer to a recent Turkish '70s nostalgia comedy film, Vizontele. One modifies the self-deprecating joke about Turkish technological backwardness, "[When I watch TV,] is Zeki Müren watching me too?" The HDP thus published social media ads where a speech bubble comes out of Vizontele lead actor Cem Yilmaz's mouth asking, "So, is Zeki Müren voting for HDP too?" This line-which equates Müren's power as a star with the surveilling power of a police force-imagines Müren's power as a benign form of surveillance. It is thus not surprising that the publicity flyers for the Zeki Müren Hotline, which lets you call and record a message addressed to Müren, also presents him as a capable of hearing you beyond the grave: "So, will Zeki Müren hear us too?" (see Figure 1). As the joke goes from seeing television viewers to voting for a popular party and to hearing people's messages, Müren's afterlife is that of a Turkish providence, not living in the flesh, but emanating from beyond to respond to Turkey's problems. 


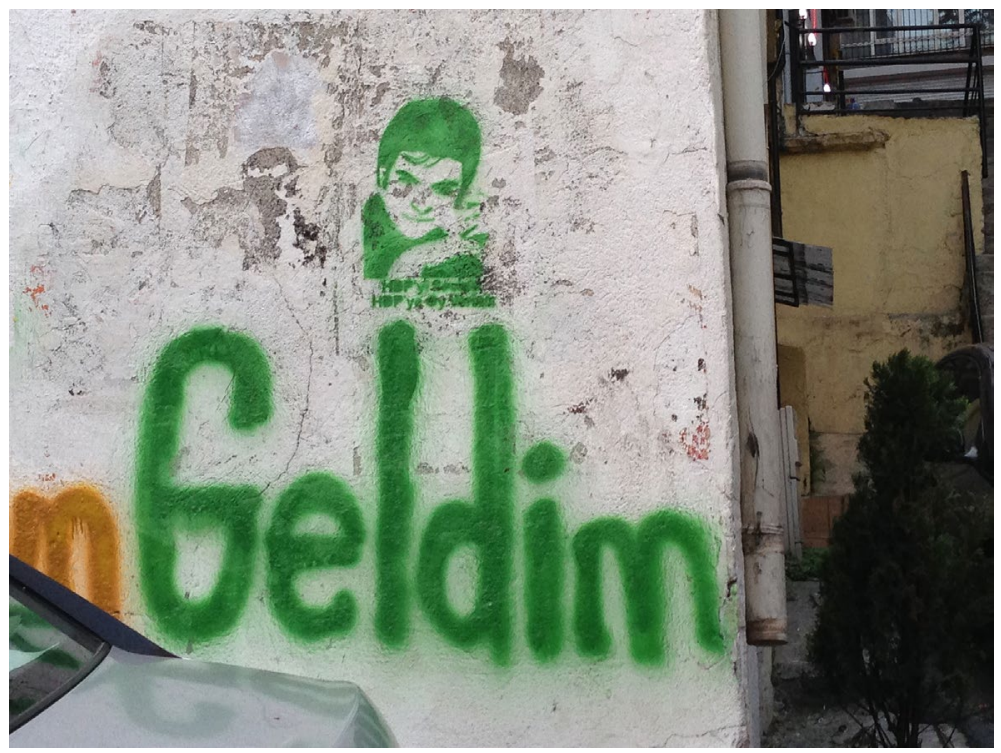

Figure 2. Street art in Beyoğlu, Istanbul, Turkey, 2015. (Text: "Vote for HDP. I voted for HDP.") Photograph: Spencer Hawkins.

HDP supporters' commitment to this advertisement campaign is clear from the stencil images of Müren, striking a familiar pose, that were spray-painted on a wall in a neighborhood in Istanbul before the July 2015 election (see Figure 2). The text beneath the image says "I have arrived," as if to indicate the arrival of a messianic figure in Turkish politics. The HDP's inclusive, liberal message does not appeal to everyone, and they have suffered persecution from over 70 attacks, including the bombing of an anti-terrorist demonstration in Ankara, which was originally planned as an attack on the HDP Ankara headquarters ("HDP, Gov't in Row over Party Office Bombings in Southern Turkey"; "LOCAL - HDP Headquarters 'Was the Original Target' of Ankara Suicide Bombers"). The imagined public created by Müren does not erase the violent lines of disagreement in Turkish politics.

In his afterlife as an icon, Müren retains a malleable and capacious identity, which the HDP adopted in hopes of bridging the Kurdish/Turkish identity difference. While Müren donated his legacy to the veterans, some of whom may have aggressively policed the southeast of Turkey during the height of concern over the Kurdish question, he was still incorporated into the social media campaign for the HDP, the pro-Kurdish party, in the 2015 election. The HDP party's success in winning $10 \%$ of the vote and thus winning parliamentary representation cannot of course be attributed to particular images selected for their campaign, but they were able to make the issues of the minority stand for the freedom of those outside that minority - the very rhetorical move that defines the democratic process, according to cultural and political theorist Jacques Rancière. In the process described by Rancière, identifying with "the uncounted...subjectifies the part of those who have no part that makes the whole different from itself" (38). Rancière is referring to the transformative effect on discourses of political inclusion when, for instance, members of the bourgeois identify with the wrongs done to proletarians. In the case of the HDP's adoption of Zeki Müren's 
image, the opposite occurs: Kurds identified their uncounted cause with the unmistakably queer (thus also excluded), but always already Turkish Zeki Müren.

Müren's choice to remain publicly "straight" preserved the implicit queerness of his performances as a signifier for whichever identities the Turkish government or society may wish to repress, but cannot forget or exclude from public consciousness. In the United States, a celebrity who so combines patriotism and queerness could have become a resource for "homonationalism," that is, the exploitation of supposed tolerance for non-normative gender and sexuality as a platform to proclaim the exceptionalism of one's own nation (Puar). Müren's image does not function this way, however, perhaps because Turkish society accepts Müren by protecting his reputation from the stigma of gayness. ${ }^{9}$ Protected from exposure, Müren is a symbol for the largesse of Turkish society, which makes a generous exception to its moral values for him. On the other hand, to see Turkish society make an exception to its values for Müren because he is an exceptional gentleman and virtuoso recalls a frightening tendency: to accept egregious violations of a society's civic values when it is a great, exceptional figure who violates them.

\section{Notes}

1. The punitive violence meted out to rape victims is a frequent subject of Turkish journalism and popular entertainment. The 1972 Turkish melodrama Namus (meaning "sexual honor") portrays the self-destructive measures that a woman might go to in order to preserve her namus after being raped. The protagonist first tries to persuade her rapist to marry her. Then, she hides the incident from her family even after he abandons her in Istanbul by selling her into prostitution. She avenges herself by killing him when he is on the verge of raping her sister-and when she herself is dying of complications from stress and medical neglect.

2. Stokes notes that Turks did not hear Müren's voice as sounding queer, only very nazik (polite) (64).

3. Persian and Turkish both use gender neutral pronouns (Tekelioğlu; Andrews and Kalpakli).

4. Here I am adapting Josh Kun's notion of "audiotopia," which is a way of listening to popular music and identifying with it that "makes audible racialized communities who have been silenced by the nationalist ear" (Kun 25).

5. The prevalance of this plot pattern was confirmed in conversation with Berkin Solak.

6. Müren would comment later that (devout) Anatolians believed that he had mastered religious chants and even learned to recite the Koran from memory, but he claims that the movie Katip was his only experience with religious chanting (see Bengi 144).

7. Düğün Gecesi follows a similar structure: Müren plays a contemporary singer. While "Zeki" is young, his father marries him to a well-off farmer's daughter, whose provincialism he abhors. She disappears and travels to America, while he builds his career and falls in love with another woman (played by Ajda Pekkan, now a major Turkish pop star). Years later, his wife disguises her name and appearance and approaches Zeki as an enterprising business woman offering him "patronage" while gradually seducing him away from his Istanbul girlfriend. Derya Bengi rightly notes that in this case the "other woman" is the Istanbul girlfriend, not the producer (Bengi 137). In this rare case, the "other woman" is less wealthy than the first.

8. Evidently, Müren saw himself as exceptionally privileged. His friend Göksenin Çakmak reports Müren walking up an unknown man at the beach and grabbing his genitals. He said to the man, "I am the only one in Turkey who they let do this. No one else is allowed" (Çınar).

9. The Turkish government does not outlaw homosexual acts, but it disallows homosexuals from performing mandatory military service. This "prohibition" is only enforced, however, if one procures an amateur pornographic video of oneself engaged in anal sex. 


\section{Disclosure Statement}

No potential conflict of interest was reported by the author.

\section{Notes on Contributor}

Spencer Hawkins is an Assistant Professor in the Program for Cultures, Civilizations, and Ideas at Bilkent University in Ankara, Turkey.

\section{ORCID}

Spencer Hawkins (iD http://orcid.org/0000-0001-8988-8162

\section{Works Cited}

Altinay, Rustem Ertug. "Reconstructing the Transgendered Self as a Muslim, Nationalist, Upper-Class Woman: The Case of Bulent Ersoy." WSQ: Women's Studies Quarterly 3 (2008): 210-229. Print.

Altuntaş, Öykü. "HDP Sosyal Medyada Gönüllülerine ve Mizaha Güveniyor [The HDP’s Social Media Campaign Relies on Volunteers and Humor]." BBC Türkçe. 6 June 2015. Web. 6 Sept 2015. $<$ www.bbc.com/turkce $>$.

Andrews, Walter G., and Mehmet Kalpakli. The Age of Beloveds: Love and the Beloved in Early-Modern Ottoman and European Culture and Society. Durham, NC: Duke UP, 2005. Print.

Arslan, Umut Tümay. "Sublime yet Ridiculous: Turkishness and the Cinematic Image of Zeki Müren." New Perspectives on Turkey 45. Special Issue, 1 (2011): 185-213. Print.

Bengi, Derya, ed. İşte Benim Zeki Müren [That's Me, Zeki Müren]. Istanbul: Yapı Kredi Yayınları, 2014. Print.

Cakirlar, C. "Queer Art of Sodomitical Sabotage, Queer Ethics of Surfaces: Embodying Militarism and Masculinity in Erinç Seymen's Portrait of a Pasha (2009)." Nowiswere: A Contemporary Art Magazine 5 (2009): 38-43. Print.

Cardoso, Fernando Luiz. "The Relationship between Sexual Orientation and Gender Identification among Males in a Cross-Cultural Analysis in Brazil, Turkey and Thailand." Sexuality and Culture 17.4 (2013): 568-597. Print.

Chakrabarty, Dipesh. Provincializing Europe: Postcolonial Thought and Historical Difference. Princeton, NJ: Princeton UP, 2000. Print.

Çınar, Ahmet. "Zeki Bey Bir Başbakanla Birlikte Oldu [Mr. Müren was Dating a Prime Minister]." Yurt Gazetesi. 6 Nov. 2014. Web. 8 June 2016.<www.yurtgazetesi.com.tr>.

Frith, Simon. Performing Rites: On the Value of Popular Music. Cambridge, MA: Harvard University Press, 1996. Print.

Genç, Kaya. “Turkey’s Glorious Hat Revolution.” Los Angeles Review of Books. 11 Nov. 2013. Web. 2 May 2016. <https://lareviewofbooks.org >.

Giaimo, Cara. "Before Bowie or Prince, There Was Zeki Müren-Turkey’s Gender-Bending Rock Star.” Atlas Obscura 9 May 2016. Web. 11 May 2016. <www.atlasobscura.com>.

Girard, René. Deceit, Desire, and the Novel: Self and Other in Literary Structure. Baltimore, MD: Johns Hopkins UP, 1976. Print.

Gökalp, Ziya. The Principles of Turkism. Leiden: Brill Archive, 1968. Print.

Görkemli, Serkan. Grassroots Literacies: Lesbian and Gay Activism and the Internet in Turkey. SUNY P, 2014. Print.

Güç, Ceyhan. Şimdi Uzaklardasın [Now You Are Far Away]. Istanbul: Ad, 1996. Print.

Gurbilek, Nurdan. "Dandies and Originals: Authenticity, Belatedness, and the Turkish Novel." The South Atlantic Quarterly 102.2/3 (2003): 599-628.

- Kör Ayna Kayıp Şark [The Blind Mirror, the Lost Orient]. Istanbul: metis, 2012. Web. 15 Nov. 2015. <www.idefix.com>. 
Halperin, David M. How To Be Gay. Cambridge: Belknap Press, 2012. Print.

"HDP, Gov't in Row over Party Office Bombings in Southern Turkey." Hurriyet Daily News 18 May 2015. Web. 29 Nov. $2015<$ www.hurriyetdailynews.com>.

Hiçyılmaz, Ergün. Dargınım Sana Hayat: Zeki Müren Için Bir Demet Yasemin [I Am Angry with You, Life: A Bouquet of Jasmines for Zeki Müren]. Istanbul: Kamer, 1997. Print.

Kaya, Cem. Motör: Kopya Kültürü \& Popüler Türk Sineması [Remake Remix Rip-off: About Copy Culture and Turkish Pop Cinema]. 2014. Istanbul. Film.

Kosofsky Sedgwick, Eve. Between Men: English Literature and Male Homosocial Desire. New York, NY: Columbia UP, 1985. Print.

Kun, Josh. Audiotopia: Music, Race, America. Berkeley, CA: U of California P, 2005. Web. 14 Nov. 2015. <www.ucpress.edu>.

"LOCAL - HDP Headquarters 'Was the Original Target' of Ankara Suicide Bombers." Hurriyet Daily News 21 Oct. 2015. Web. 29 Nov. 2015. <www.hurriyetdailynews.com>.

Necef, Mehmet Ümit. “Turkey on the Brink of Modernity: A Guide for Scandinavian Gays.” Sexuality and Eroticism Among Males in Moslem Societies. Eds. Arno Schmitt and Jehoeda Sofer. Hove, UK: Psychology Press, 1992. 71-75. Print.

Özgür, İren. "Arabesk Music in Turkey in the 1990s and Changes in National Demography, Politics, and Identity." Turkish Studies 7.2 (2006): 175-190. Print.

Puar, Jasbir. Terrorist Assemblages: Homonationalism in Queer Times. Durham, NC: Duke UP, 2007. Print.

Pullen, Christopher. LGBT Transnational Identity and the Media. Basingstoke, UK: Palgrave, 2012. Print.

Rancière, Jacques. Dis-Agreement: Politics and Philosophy. Minneapolis, MI: U of Minnesota P, 1999. Print.

Rubin, Gayle. "The Traffic in Woman: Notes on the 'Political Economy of Sex"' Toward an Anthropology of Women. New York, NY: Monthly Review Press, 1975. 157-210. Print.

Selen, Eser. “The Stage: A Space for Queer Subjectification in Contemporary Turkey." Gender, Place \& Culture 19.6 (2012): 730-749. Print.

Stokes, Martin. The Republic of Love. Chicago, IL: U of Chicago P, 2010. Print.

Tekelioğlu, Orhan. "The Rise of a Spontaneous Synthesis: The Historical Background of Turkish Popular Music." Middle Eastern Studies 32.2 (1996): 194-215. Print.

Televizyon 2. Program Yayınları Kamuoyu Araştırması (Ocak-Şubat 1987) [Second television program public opinion study (January-February 1987)]. Ankara: TRT Yayın Planlama Koordinasyon ve Değerlendirme Dairesi Başkanlığı, 1987. Print.

Traub, Valery. "The Past Is a Foreign Country?: The Times and Spaces of Islamicate Sexuality Studies." Islamicate Sexualities: Translations across Temporal Geographies of Desire. Eds. Kathryn Babayan and Afsaneh Najmabadi. Cambridge, MA: Harvard UP, 2008. 1-40. Print.

Turan, Nurten. Remembering Zeki Müren. 24 Oct. 2015.

Warner, Michael. The Trouble with Normal: Sex, Politics, and the Ethics of Queer Life. New Ed edition. Cambridge, MA: Harvard UP, 1999. Print.

Worth, Robert F. “Behind the Barricades of Turkey's Hidden War." The New York Times. 24 May 2016. Web. 9 June 2016.

Yildirim, A. Kadir. Turkey's Democratic Struggles: Turkey's Kurdish Party at the Threshold. Project on Middle East Political Science, 2015. Web. 1 Apr 2016. <pomeps.org>.

\section{Discography}

Müren, Zeki. Ayrıldık Işte [That Was How We Separated]. Istanbul: Yavuz \& Burç, 1989. Audio Recording. . Eskimeyen Dost [The Friend Who Does Not Age]. Istanbul: Türküola Müzik, 1982. Audio Recording. . Hayat Öpücü̆g̈̈ [The Kiss of Life]. Istanbul: AJS, 1984. Audio Recording. Masal [Fairy Tale]. Istanbul: Lider Müzik, 1985. Audio Recording. 